\title{
The Role of Leadership and Influence on Employee Performance in Digital Era
}

\author{
Dedi Iskamto
}

Sekolah Tinggi Ilmu Ekonomi Riau

dediiskamto@lecturer.stieriau-akbar.ac.id

\section{ABSTRACT}

This research is a quantitative discretive research. According to Sugiono (2010), quantitative descriptions are research by drawing a conclusion from the data tabulated in the form of frequency distribution tables. The location of this research is at PT Mitra Beton Mandiri (MBM), Pekanbaru Riau City. The sample sample is 67 people. The results showed bbased on the total average value of the leadership recapitulation results, it is known that the respondent's response to the statement on the leadership variable is agree with the average value of 3.95\%. From these data it can be seen that the leadership is good. Based on the average value of the performance recapitulation results, it is known that the respondent's response to the statement on the performance variable is in agreement with the average value of $4.00 \%$. From these data it can be concluded that the employee's performance is good. Based on the results of the recapitulation of the leadership variable with the lowest average score for the tenth question with an average score of 3.83, which is for the achievement orientation indicator. Based on the results of the recapitulation of performance variables with the lowest average score for the eleventh question with an average score of 3.90, namely for the Communication indicator.

\section{Keywords: Leadership; Performance; Achievement; Leadership; Performance}

\begin{abstract}
ABSTRAK
Penelitian ini merupakan penelitian Diskritif Kuantiatif. Menurut Sugiono (2010), deskripsi Kuantiatif adalah penelitan dengan menarik suatu kesimpulan dari data yag ditabulasikan dalam bentuk tabel-tabel distribusi frekuensi. Adapun lokasi penelitian ini adalah pada PT Mitra Beton Mandiri (MBM), Kota Pekanbaru Riau. Sampel sampel sebanyak 67 orang. Hasil penelitian menunjukan berdasarkan jumlah nilai rata-rata dari hasil rekapitulasi kepemimpinan diketahui bahwa tanggapan responden terhadap pernyataan pada variabel kepemimpinan adalah setuju dengan jumlah nilai rata-rata 3,95\%. Dari data tersebut dapat diketahui bahwa kepemimpinan sudah baik. Berdasarkan jumlah nilai rata-rata dari hasil rekapitulasi kinerja diketahui bahwa tanggapan responden terhadap pernyataan pada variabel kinerja adalah setuju dengan jumlah nilai rata-rata 4,00\%. Dari data tersebut dapat diambil kesimpulan bahwa kinerja karywana sudah baik. Berdasarkan hasil rekapitulasi variabel kepemimpinan dengan skor rata-rata terendah untuk pertanyaan kesepuluh dengan skor rata-rata 3,83 yaitu untuk indikator orientasi prestasi. Berdasarkan hasil rekapitulasi variabel kinerja dengan skor ratarata terendah untuk pertanyaan kesebelas dengan skor rata-rata 3,90 yaitu untuk indikator Komunikasi.
\end{abstract}

Kata Kunci: Kepemimpinan; Kinerja; Prestasi; Kepemimpinan; Kinerja 


\section{INTRODUCTION}

The development of the business world today is required to maintain and improve the quality of work and quality of work. This is so that the company can compete with other similar companies, both at the national and international levels. One of the important parts that play a role in determining the success of a company is the development of a potential workforce. The company strives to find and foster employees with high enthusiasm, to create and maintain competitive human resources (Bahari et al., 2018). According to Iskamto (2012) Managing human resources is very complete, because you have to deal with people who have different educational backgrounds, character, social life. Therefore it is necessary to have a policy from a leader who is appropriate and directed from the agency in overcoming this human resource problem, because the implementation of the wrong policy will have a negative impact on the organization as a whole. The success of an organization is greatly influenced by the performance of its employees. To achieve maximum performance, the company must be able to create conditions that can encourage and enable employees to develop and improve their abilities and improve their optimal skills. (Iskamto et al., 2020b; Khajeh, 2018; Wiandari and Darma, 2017).

Performance is the result of work done by employees in doing their job. Every company wants the best performance from its employees so that the company's activities run well. In order for the company's goals to be properly achieved, every company must provide an assessment of the work performed by its employees. This aims to assist in correcting mistakes made by employees in carrying out their duties (Iskamto, 2019). Employee performance will be achieved if employees are able to do work in accordance with the system provided by the company, so that the company's vision and mission can be fulfilled properly. One way to achieve the company's goals is if employees are able to comply with the regulations given by the leadership (Ibrahim and Daniel, 2019).

In accordance with the Hurduzeu (2015) An effective leader is a leader who successfully directs and moves a person and group to carry out all planned activities in an effort to carry out all planned activities in an effort to achieve predetermined goals.

Leadership behavior that can motivate and direct employees will have an effect on employee performance outcomes later. Employees are social beings who are the main wealth of the company, these employees are planners, implementers, and controllers who are always active in the company who have thoughts, feelings and desires that can influence their attitudes at work. This attitude can determine the work performance and love for the job assigned to him(Iskamto and., 2020; Iskamto et al., 2020a; Asri and Darma, 2020). Leader is something 
that can provide leadership behavior that can motivate and direct employees. Employees are social beings who are the main wealth of the company, these employees are planners, implementers, and controllers who are always active in the company who have thoughts, feelings and desires that can influence their attitudes at work. This attitude can determine the work performance and love for the job assigned to him/her.

\section{Leadership}

Leadership is very important in managerial, because with leadership, the manajement process will run better and employees will be passionate about doing their job. The definition of leadership, then the process of influencing in determining organizational goals, motivating the behavior of subordinates in achieving the goal of influencing to improve the group and culture. In addition, it also influences the interpretation of the events of his subordinates, achieves goals, maintains cooperative relationships and group work and the cooperation of people outside the group. Robert House in syamsul (2012: 30) says that leadership is a way for someone to use domination and have self-confidence to influence and display high morality to their subordinates. Hasibuan (2012: 170) Leadership is a way for a leader to influence the behavior of subordinates, so that they are willing to work together and work productively to achieve organizational goals. Meanwhile, according to George R. Terry in Miftah Toha (2010: 259) formulates that leadership is an activity to influence people to be directed towards achieving organizational goals. Based on the opinion of the experts above, leadership is an activity to influence the behavior of others or art to influence human behavior, both individually and in groups. Here, leadership does not have to be limited by rules of bureaucratic etiquette. Leadership does not have to be tied up in a particular organization. But leadership can occur anywhere, as long as someone shows their ability to influence the behavior of others and achieve certain goals Thoha (2010: 9).

\section{Leadership Indicators}

According to Robert House in Syamsul (2012: 30) which states there are four dimensions or indicators in leadership:

a. The directive consists of: 1) Employees know what the leader expects from their performance. 2) Special direction from the leader.

b. Supportive consists of: 1) Able to create a conducive working atmosphere. 2) pay attention to employee welfare.

c. Participative consists of: 1) Providing freedom of opinion. 2) Consider suggestions. 
d. Achievement-oriented leadership consists of: 1) Setting goals. 2) Shows confidence that employees can achieve high standards.

\section{Performance}

A company is formed to achieve common goals, but to achieve goals effectively requires good performance. Performance is a tangible behavior that is displayed by everyone as a work achievement that is produced by employees in accordance with their role in the company. Work management is about creating relationships and ensuring effective communication between employees and their superiors. Performance is the result of work that has a strong relationship with the strategic objectives of the company to be managed. The performance of a company is very much determined by the human resources in it. If the human resources are highly motivated, creative and able to develop innovation, their performance will be even better. Therefore, it is necessary to have efforts to improve human resource capabilities. Performance is the result or output of a process (Nurlaila, 2010: 71; Artawaijaya and Darma, 2015).

Hasibuan (2012: 195) states the following performance "Performance or for work is the result of work produced by employees or tangible behavior that is displayed in accordance with their role in the organization". Mangkunegara (2016: 67) the term performance comes from the word job performance or Actual Performance (work performance or actual achievement someone has achieved). The definition of performance is the quality and quantity of work achieved by an employee in carrying out his duties in accordance with the responsibilities assigned to him. Edison (2016: 190) Performance is the result of a process that refers and is measured over a certain period of time based on provisions or agreements that have been previously determined.

\section{Measuring Employee Performance}

According to Wilson Bangun (2012: 234) A job can be measured through :1) Number of jobs. This dimension shows the amount of work produced by individuals or groups as a requirement that becomes the standard of work. 2) Quality of Work. Every employee in the company must meet certain requirements to produce work according to the quality that is guided by a particular job. 3). Punctuality. Every job has different characteristics, for certain types of work must be completed on time, because it has dependence on other jobs. 4) Presence, A certain job requires the presence of employees in working on a predetermined time. 5). 
Cooperation ability. Not all work can be completed by just one employee. Two people may have to complete certain types of work.

\section{Employee Performance Indicators}

To facilitate the assessment of employee performance, (Sedarmayanti. 2019: 51) suggests the following indicators:

a. Work quality

It is the quality of work that is achieved based on requirements of high suitability and readiness which in turn will give rise to appreciation and progress and organizational development by systematically increasing skill knowledge in accordance with the increasingly rapidly developing demands of science and technology.

b. Punctuality

Is related to whether or not the completion time of work is appropriate with the planned target time. Attempted to finish every job according to plan so as not to interfere with other work.

c. Initiative

Is to have the awareness of yourself to do something in carrying out duties and responsibilities. Subordinates or employees can carry out tasks without having to depend continuously on the boss.

d. Ability

It is among the several factors that influence a person's performance that it can be treated through education and training.

e. Communication

It is an interaction between superiors and subordinates to express their suggestions and opinions in solving the problem at hand. Communication leads to better cooperation and an increasingly harmonious relationship between employees and superiors which can also lead to feelings of similarity and acceptance.

\section{The Influence of Leadership on Employee Performance}

Several research results show that leadership set by a manager (leadership) in an organization can create harmonious integration and encourage employee morale to achieve maximum motivation. The drive and leadership spirit possessed by a leader can influence and move his subordinates in the desired direction. Irham Fahmi (2014: 18). According to Handoko (2011), to achieve maximum performance, companies must be able to create conditions that can encourage and enable employees to develop and improve their abilities and skills 
optimally. One of the factors that influence employee performance is leadership. The relationship between leadership and employee performance based on the path-goal theory,

\section{RESEARCH METHODS}

This research is a quantitative discretive research. According to Suharmi Arikunto, descriptions are comparing actual facts with theories related to problems in order to draw conclusions and tabulated in the form of frequency distribution tables. Is research data derived from numbers and analysis using statistics. The location of this research is at PT Mitra Beton Mandiri (MBM), Pekanbaru Riau City. The sample sample is 67 employees because there is one person who is not included in the sample is the leader.

\section{Research Instruments}

In the form of a questionnaire, namely data collection by submitting statements to respondents and then answering them. The data obtained are in the form of answers submitted and arranged in the form of a questionnaire. Sugiyono (2009: 86) argues that one of the most frequently used ways to determine a score is to use a Likert scale, which is a measurement of the answers to questions symbolized by a scale. Likert scale is used to measure respondents' answers to the research variables. Because there are a number of statements as a tool for collecting data or information from respondents.

Table 1. Descriptive Criteria Determination Reference Scale range

$1.00-1.80$

$1.81-2.60$

$2.61-3.40$

$3,41-4,20$

$4.21-5.00$
Performance

Strongly Disagree

Disagree

Doubtful

Agree

Strongly agree

Source: Sugiono (2015)

\section{RESULTS AND DISCUSSION}

\section{Respondent Identity Description}

Based on the results of research conducted on 67 respondents who were sampled, namely all employees of PT. Independent Concrete Partners (MBM). There are 4 
characteristics of respondents included in this study, namely the identity of the respondents based on gender, education level, age and length of work. All of the identities questioned in the questionnaire are characteristics that are considered appropriate to support this research. Based on the questionnaire that has been distributed by the researcher, the respondents are obtained according to the characteristics as in the following table:

Table 2. Number of Respondents Based on characteristics

Information total Percentage (\%)

\section{Gender}

Male

54

80.6

Women

13

19.4

\section{Level of education}

High School

20

29.9

Diploma

Degree

Age

$<30$

30

5

$41-50$

$>50$

\section{Length of work}

$<3$ years

4 - 7 Years

8 - 10 Years
46.3

44.8
13

19.4

12
17.9

Source: Processed Data, 2020

From the data in table 5.1. It is known that the respondents in this study were dominated by male employees, namely 54 people $(80.6 \%)$ and the remaining 13 female respondents (19.4\%). Furthermore, respondents with high school / vocational education level were 20 people (29.9\%). Respondents with D3 education level were 19 people (28.3\%) and respondents 
with S1 education were 28 people (41.8\%). Furthermore, the respondents who were less than 30 years old were 31 people (46.3\%), 31 to 40 years old as many as 30 people $(44.8 \%), 5$ people aged 41 to 50 years $(7.4 \%)$ and respondents who 1 person (1.5.\%) aged more than 50 years. And the last respondents based on the length of work less than 3 years were 42 people $(62.7 \%)$, respondents who worked from 4 to 7 years were 13 people $(19.4 \%)$,

\section{Validity test}

Before carrying out further testing, the validity and reliability of the data generated from the distribution of the questionnaire were tested so that the resulting data was accurate and reliable. Validity testing in this study uses the Pearson product moment correlation formula. The complete calculation results using SPSS are as follows:

Table 3. Results of the Leadership Variable Validity Test r-Count

Statement

(Pearson

r-Table Ket. Correlation)

\begin{tabular}{lllll}
\hline 1 & Item1 & 0.480 & 0.2404 & Valid \\
2 & Item2 & 0.512 & 0.2404 & Valid \\
3 & Item3 & 0.677 & 0.2404 & Valid \\
4 & Item4 & 0.577 & 0.2404 & Valid \\
5 & Item5 & 0.701 & 0.2404 & Valid \\
6 & Item6 & 0.375 & 0.2404 & Valid \\
7 & Item7 & 0.737 & 0.2404 & Valid \\
8 & Item8 & 0.614 & 0.2404 & Valid \\
9 & Item9 & 0.702 & 0.2404 & Valid \\
10 & Item 10 & 0.635 & 0.2404 & Valid \\
11 & Item 11 & 0.662 & 0.2404 & Valid \\
12 & Item 12 & 0.570 & 0.2404 & Valid \\
\hline
\end{tabular}

Source: Processed data, 2020 
The validity test for performance variables can be seen below.

Table 4.Validity Test Results of Performance Variables

\begin{tabular}{lcccc}
\hline Statement & $\begin{array}{c}\text { r-Count } \\
\text { (Pearson } \\
\text { Correlation) }\end{array}$ & r-Table & Ket. \\
\hline 1 & Item1 & 0.492 & 0.2404 & Valid \\
2 & Item2 & 0.527 & 0.2404 & Valid \\
3 & Item3 & 0.639 & 0.2404 & Valid \\
4 & Item4 & 0.514 & 0.2404 & Valid \\
6 & Item5 & 0.568 & 0.2404 & Valid \\
7 & Item6 & 0.584 & 0.2404 & Valid \\
8 & Item7 & 0.530 & 0.2404 & Valid \\
9 & Item8 & 0.534 & 0.2404 & Valid \\
10 & Item9 & 0.672 & 0.2404 & Valid \\
11 & Item 10 & 0.424 & 0.2404 & Valid \\
\hline
\end{tabular}

Source: Processed Data, 2020

Based on table 4. above, the results of the calculation of the validity test of the training and performance variables concluded that all 23 items of measuring instruments were declared valid.

\section{Reliability Test}

The reliability value needs to be known as a reference for the reliability of the variables used in this study. Reliability testing was carried out by using the split half technique, which was analyzed using the Spearman Brown formula and processed using SPSS. The results of reliability for the two variables in this study can be seen in table 5. as follows: 
Table 5. Reliability Test Results

\begin{tabular}{cccc}
\hline Variable & $\begin{array}{c}\text { Reliability } \\
\text { Limit }\end{array}$ & Cronbach's Alpha & Information \\
\hline Leadership & 0.60 & 0.893 & Reliable \\
Performance & 0.60 & 0.842 & Reliable \\
\hline
\end{tabular}

Source: Processed data, 2020

Reliability test results are in table 5.28. above, shows that the coefficient value $a$ (Alpha) of the variables studied showed mixed results and the variable Cronbach's Alpha value was greater than 0.60 . Thus, it can be concluded that the measuring instrument used in this waiting was reliable.

\section{Shapiro Wilk Normality Test}

This test is part of the noermality test which is used to test whether the data is normally distributed or not, it can be seen in the table below:

Tests of Normality

\begin{tabular}{|l|r|r|r|r|r|r|}
\hline & \multicolumn{3}{|c|}{ Kolmogorov-Smirnova } & \multicolumn{3}{c|}{ Shapiro-Wilk } \\
\cline { 2 - 7 } & Statistics & df & Sig. & Statistics & df & \multicolumn{1}{c|}{ Sig. } \\
\hline leadership &, 138 & 67 &, 003 &, 965 & 67 &, 056 \\
Performance &, 056 & 67 &, $200 *$ &, 978 & 67 &, 265 \\
\hline
\end{tabular}

*. This is a lower bound of the true significance.

a. Lilliefors Significance Correction

Based on the above test, it can be seen that the value of the Shapiro Wilk test is said to be normally distributed if the significance value $>$ from 0.05 and vice versa, it can be seen that 0.056 for leadership and 0.265 for performance, so that these data are normally distributed data. Based on table 6 . below, it can be seen that the recapitulation of the questionnaire results on the leadership variable with an average score of 3.94 shows that the respondent's response to the question on the leadership variable is agree. The highest score for the seventh question with an average score of 4.06 is for the question that the leader gives freedom of opinion, while the lowest average score for the twelfth question with an average score of 3.83 is for the question that the leader can generate employee confidence to be able to complete tasks. 
Table 6. Recapitulation of Respondents' Responses to Leadership variables

\begin{tabular}{|c|c|c|c|c|}
\hline Indicator & Question & $\begin{array}{l}\text { Std. } \\
\text { Deviation }\end{array}$ & Average & Average \\
\hline \multirow[t]{3}{*}{ Directive } & $\begin{array}{l}\text { The leader told me what to expect from } \\
\text { my performance }\end{array}$ & 0.77792 & 3.98 & \multirow{3}{*}{3.97} \\
\hline & $\begin{array}{l}\text { Leaders always provide specific } \\
\text { instructions for each complex task }\end{array}$ & 0.81650 & 4.0 & \\
\hline & $\begin{array}{l}\text { The leader will direct the employees } \\
\text { before the assignment is given }\end{array}$ & 0.72433 & 3.93 & \\
\hline \multirow[t]{3}{*}{ Supportive } & $\begin{array}{l}\text { Leaders are able to create a conducive } \\
\text { work atmosphere }\end{array}$ & 0.88584 & 3.87 & \multirow{3}{*}{3.93} \\
\hline & $\begin{array}{l}\text { Leaders always pay attention to the } \\
\text { welfare of employees }\end{array}$ & 0.85068 & 3.95 & \\
\hline & $\begin{array}{l}\text { Leaders are able to grow and develop } \\
\text { employee abilities }\end{array}$ & 0.82449 & 3.96 & \\
\hline \multirow[t]{3}{*}{ Participative } & Leadership provides freedom of opinion & 0.90253 & 4.06 & \multirow{3}{*}{3.99} \\
\hline & $\begin{array}{l}\text { Leaders always consider suggestions } \\
\text { given by employees }\end{array}$ & 0.87892 & 4.02 & \\
\hline & $\begin{array}{l}\text { Leaders always lead to guide their } \\
\text { employees }\end{array}$ & 0.81899 & 3,9 & \\
\hline \multirow[t]{4}{*}{ achievement } & $\begin{array}{l}\text { Leaders set a series of goals with their } \\
\text { employees }\end{array}$ & 0.83349 & 3.83 & \multirow{3}{*}{3.90} \\
\hline & $\begin{array}{l}\text { Leaders invite employees to participate } \\
\text { in achieving goals }\end{array}$ & 0.77617 & 3.95 & \\
\hline & $\begin{array}{l}\text { Leaders can generate confidence in } \\
\text { employees to complete tasks }\end{array}$ & 0.76502 & 3.93 & \\
\hline & \multicolumn{2}{|l|}{ Total Average } & 3.95 & 3.95 \\
\hline
\end{tabular}

Source: Processed data, 2020

Based on table 7.Below can be seen the recapitulation of the results of the questionnaire on the performance variable with an average score of 4.00 indicating that the respondent's response to the question on the performance variable is agree. The highest score for the eighth question with an average score of 4.10 is for the question that the work I have done has reached the target set by the company, while the lowest average score is for the eleventh question with an average score of 3.90, which is for the question that I can cooperate with colleagues in carrying out the work that is assigned. 
Table 7. Recapitulation of Respondents' Responses to Performance variables

\begin{tabular}{|c|c|c|c|c|}
\hline Indicator & Question & $\begin{array}{l}\text { Std. } \\
\text { dev }\end{array}$ & Average & Average \\
\hline \multirow[t]{2}{*}{ Work quality } & I do a job with the quality standards set & 0.75640 & 3.95 & \multirow{2}{*}{3.97} \\
\hline & I do a job with calculation and accuracy & 0.85227 & 3.98 & \\
\hline \multirow[t]{3}{*}{ Punctuality } & $\begin{array}{l}\text { Sayan always comes and goes home } \\
\text { according to schedule }\end{array}$ & 0.84052 & 4.07 & \multirow{3}{*}{4.03} \\
\hline & $\begin{array}{l}\text { I always carry out my work according to } \\
\text { the time limit set }\end{array}$ & 0.75819 & 4.02 & \\
\hline & $\begin{array}{l}\text { For me, completion of work on time is } \\
\text { important and must be achieved }\end{array}$ & 0.85227 & 4.02 & \\
\hline \multirow[t]{2}{*}{ Initiative } & $\begin{array}{l}\text { In completing work I am able to work } \\
\text { independently }\end{array}$ & 0.76738 & 3.96 & \multirow{2}{*}{4.02} \\
\hline & I already know how to do a good job & 0.77325 & 4.08 & \\
\hline \multirow[t]{2}{*}{ Ability } & $\begin{array}{l}\text { The work I have done has reached the } \\
\text { target set by the company }\end{array}$ & 0.92334 & 4,1 & \multirow{2}{*}{4.03} \\
\hline & $\begin{array}{l}\text { I am able to complete the job beyond } \\
\text { the specified target }\end{array}$ & 0.82449 & 3.96 & \\
\hline \multirow[t]{3}{*}{ Communication } & $\begin{array}{l}\text { For me, coordinating with superiors and } \\
\text { working with colleagues is important }\end{array}$ & 0.75819 & 4.02 & \multirow{2}{*}{3.96} \\
\hline & $\begin{array}{l}\text { I can work together with colleagues in } \\
\text { carrying out the assigned work }\end{array}$ & 0.86203 & 3.90 & \\
\hline & Average score $=44.6 / 11$ & & 4.00 & 4.00 \\
\hline
\end{tabular}

Source: Processed data, 2020

\section{CONCLUSION}

From the description that the author has previously put forward, the authors draw several conclusions, including: Based on the total average value of the leadership recapitulation results, it is known that the respondent's response to the statement on the leadership variable is agree with the average value of $3.95 \%$. From these data it can be seen that the training at PT. Mitra Beton Mandiri Pekanbaru is good. Based on the average value of the performance recapitulation results, it is known that the respondent's response to the statement on the performance variable is in agreement with the average value of $4.00 \%$. From these data it can be concluded that the employee's performance is good. Based on the results of the recapitulation of the leadership variable with the lowest average score for the tenth question with an average score of 3.83, namely for the question that the leader sets a series of goals with his employees. It is better if leaders pay more attention to the existence of their employees so 
that employees can know and be responsible for their work. Based on the results of the recapitulation of performance variables with the lowest average score for the eleventh question with an average score of 3.90, namely for the question that employees can cooperate with colleagues in carrying out the work that is charged. We recommend that employees get closer to themselves and be able to mingle with fellow colleagues to make work easier. 


\section{REFERENCE}

Amini, S.H. (2018). Pengaruh kepemimpinan terhadap kinerja karyawan pada PT Sinar Makmur Ansari Sejahtera Pekanbaru. Pekanbaru. STIE RIAU.

Ariska, D. (2018). Pengaruh Motivasi, Disiplin dan Keselamatan Kerja karyawan. Fakultas Ekonomi dan Bisnis UMP.

Asri, A. A. S. M. A. N., \& Darma, G. S. (2020). Revealing the digital leadership spurs in 4.0 industrial revolution, International Journal of Business, Economics \& Management, 3 (1): 93-100. https://doi.org/10.31295/ijbem.v3n1.135.

Artawijaya, I.G.P.A., and Darma, G.S. (2015). Evaluation The Effectivity of Performance Management Online System to Improving The Employees Performance, Jurnal Manajemen \& Bisnis, 12 (2): 73-89.

Bahari, N., Yunus, A.R., Jabar, J.A., Yusof, S.W.M. (2018). Entrepreneur Characteristics and Firm Performance: A Study on Malaysian Food Manufacturing Industry Sme's, IOSR Journal of Humanities and Social Science (IOSR-JHSS), 23: 92-98. https://doi.org/10.9790/0837-2302079298.

Bangun, W. (2012). Manajemen Sumber Daya Manusia. Bandung: Erlangga.

Cahyono, A. (2012). Analisis Pengaruh Kepemimpinan, Motivasi, dan Budaya Organisasi Terhadap Kinerja Dosen dan Karyawan di Universitas Pawyatan Daha Kediri, Jurnal Ilmu Manajemen Revitalisasi, 1 (1).

Fahmi, I. (2014). Dorongan dan Semangat Kepemimpinan yang Dimiliki oleh Seorang Pemimpin Mampu Mempengaruhi dan Menggerakan Bawahannya Kearah yang Diinginkan. Bandung: Alfabeta.

Hasibuan. (2012). Manjemen Sumber Daya Manusia. Edisi Revisi. Jakarta: Bumi.

Hasibuan, S.P.M. (2012). Kepemimpinan (Leadership). Jakarta: PT Bumi Aksara.

Hurduzeu, R.-E. (2015). The Impact of Leadership Literature Reviews, Practical Aplication of Science, III (6).

Ibrahim, A.U., Daniel, C.O. (2019). Impact of Leadership on Organisational Performance, International Journal of Business Management and Social Research, 6: 367-374. https://doi.org/10.18801/ijbmsr.060219.39.

Iskamto, D. (2020). Analysis of Atittude factors Toward Entrepreneurial Intention in Indonesian, in: KnE Social Sciences. Presented at the International Conference on Islam, Economy, and Halal Industry, Knowledge E. https://doi.org/10.18502/kss.v4i9.7346

Iskamto, D. (2012). Persoalan sumber daya manusia dalam pengembangan ekonomi Islam, Eko dan Bisnis (Riau Economics and Business Review), 3. 
Iskamto, D. (2019). Disiplin Kerja dan Pengaruhnya Terhadap Kinerja Karyawan Pada PT. Prima Rintis Sejahtera Pekanbaru Divisi Unicharm, Ekonomi Bisnis, 24 (12). https://doi.org/10.17977/um042v24i1p12-20.

Iskamto, D., Puspa Liza Ghazali, Aftanoorhan, A., Narti, S. (2020). Effect of Occupational Safety And Health on Performance: An Empirical Investigation, International Journal of Islamic Studies and Social Sciences, 1 (20).

Iskamto, D., Yapentra, A., Budi Ansori, P., Jupri, M. (2020). Effect of Working Discipline Toward Performance: An Empirical Investigation, in: KnE Social Sciences. Presented at the International Conference on Islam, Economy, and Halal Industry, Knowledge E. https://doi.org/10.18502/kss.v4i9.7347.

Khajeh, E.H.A. (2018). Impact of Leadership Styles on Organizational Performance, Journal of Human Resources Management Research, 10.

Marwansyah. (2010). Manajemen Sumber Daya Manusia. Bandung: Alfabeta.

Moch, D.T., Mukzam, D., \& Nurtjahjono, G.E. (2014). Pengaruh Pelatihan Kerja terhadap Kinerja Karyawan (Pelatihan pada Karyawan PT Pos Indonesia (Persero) Cabang Kota Kediri), Jurnal Administrasi Bisnis: (JAB), 12 (1).

R.Terry, G. (2010). Kepemimpinan. Jakarta: Bumi aksara.

Sedarmayati. (2012). Sumber Daya Manusia, Reformasi Birokrasi dan Manajemen Pegawai Negeri Sipil, cetakan kelima. Bandung: PT Refika Aditama.

Subagyo, J. (2015). Observasi dan Kuesioner atau Angket. Jakarta: Rineka Cipta.

Sugiyono. (2010). Metode Penelitian Kualitatif Kuantitatif dan R\&D. Bandung: Alfabeta.

Sugiyono. (2012). Statistik untuk penelitian kualitatif. Bandung: CV. Alfabeta.

Suwatno dan Priansa. (2011). Manajemen SDM Dalam Organisasi Publik dan Bisnis. Bandung: Alfabeta.

Umar, H. (2011). Metode Penelitian untuk skripsi Dan Tesis Bisnis. Jakarta: PT Raja Grafindo. Wibowo. (2013). Manajemen Kinerja. Jakarta: Rajawali Press.

Wijayanti, D.W. (2012). Pengaruh Kepemimpinan dan Motivasi Terhadap Kinerja Karyawan Pada PT Daya Anugerah Semesta Semarang. Universitas Negeri Semarang.

Wiandari, I.A.A., and Darma, G.S. (2017). Kepemimpinan, Total Quality Management, Perilaku Produktif Karyawan, Kinerja Karyawan dan Kinerja Perusahaan, Jurnal Manajemen \& Bisnis, 14 (2): 61-78.

Yani. (2012). Manajemen Sumber Daya Manusia. Jakarta: Mitra Wacana Media. 